\title{
Knowledge among Military Commanders in Motivating Non-Commissioned Officers in the Infantry
}

\author{
Endry Nixon A. \\ Graduate School of Management, Universiti Putra Malaysia, Malaysia
}

\begin{abstract}
Motivation is taken seriously by most military forces as it is a crucial for success in military missions. As much as motivation is an important factor in the military, knowledge in motivation is equally pertinent for military commanders as part of their human resource management function. Knowledge conceived as conceptual, contextual and operational are pertinent as it emphasizes not only knowing what to do but rather how to interpret what to do into practical implications. This paper aims to establish how well military commanders are in motivating their non-commissioned officers (NCOs) and the level of knowledge among military commanders in motivating NCOs in the infantry regiments. A quantitative approach was taken to determine empirically how satisfied are the NCOs motivated by their military commanders and the level of knowledge in motivating NCOs among military commanders, specifically in the Malaysian Infantry. The findings indicate that $63.3 \%$ of the respondents rated between very satisfied and satisfied for their military commanders in motivating NCOs and there is a similarity in the level of knowledge in motivating NCOs among the military commanders in the Malaysian Infantry. The findings imply that although all military commanders have a similar level of knowledge in motivating NCOs but not all are able to put their knowledge into practice. The paper will be able to contribute an understanding to motivating NCOs among military commanders in the Malaysian Infantry for subsequent measures in enhancing human resource management in the organization. In addition, from a practical perspective, the study proposes knowledge elicitation of relevant knowledge in motivating NCOs for the purpose of training potential military commanders.
\end{abstract}

Keywords: Knowledge, Motivation, Military Commanders

\section{Introduction}

Motivation has always been an emphasis in human resource management, where organizations are eager not only to know what motivates their employees but most importantly how to motivate them. Studies illustrate that motivation from the organization or employer perspective is to seek to meet the needs, goals and desires of their human resource (Cole, 2004;
Srinivasan, 2008). Wright and Mcmahan (1992) advocate that motivated workers are a critical resource in an organization. Since management is the prime factor in motivating people, it is pertinent that organizational leaders are continuously reviewing the means and approaches to sustain motivation among their employees (Dingley, 1986). Likewise in the military, motivation plays an important role as a highly motivated force is essential to

Copyright (c) 2012 Endry Nixon A. This is an open access article distributed under the Creative Commons Attribution License unported 3.0, which permits unrestricted use, distribution, and reproduction in any medium, provided that original work is properly cited. Contact author: Endry Nixon A E-mail: nixonendry@yahoo.com 
succeed in military missions (Primortz, 2002; Sergio, 2004; MacCoun, Kier and Belkin, 2005; Blocq, 2010). History illustrates those quantitatively inferior armies have been able to win battles and conflicts because of their fighting spirit, aggressiveness and high morale brought about by motivation (Sergio, 2004). Studies in the military also indicate that motivation among soldiers is a critical factor in managing human resource in the military (MacCoun et al, 2005; Lewin, 2006; BenDor et al, 2008).

According to Greger and Peterson (2000), "A Leader must have a broad knowledge of the field which comes from experience as well as from reading, listening and talking to people". In the profile of a leader: the Wallenberg effect also depicts that success is largely based on knowledge (Kunich and Lester, 1994).Similarly, in the military, efforts have been taken to capture knowledge that is experience-based, practically relevant, insights, and beliefs that are able to enhance military professionalism (Sternberg, 2000; Hedlund et al, 2003). Other studies such as Mumford et al, (2000); Zaccaro et al, (2003) and Helund et al, (2003) have too established the need for acquiring knowledge to improve the ability of organizational leaders in performing their responsibilities in managing human resource. As the military commander's role in motivation is to understand the needs and desires of his subordinates and subsequently align them towards the organizational goals, it is of utmost importance to have a sound knowledge on what is needed and the manner to influence them. In this perspective, knowledge becomes a key resource that enables a military commander to be capable in motivating their subordinates (Alonderienne, 2006; Shahwanaz, 2008; Samiolis, 2003) Knowledge is pertinent as it relates to the domain of action that needs to be undertaken to motivate people towards accomplishing a task (Tsoukos, 2000;
Weick, 1995). The importance of knowledge was also echoed by Guzman (2009) as practical knowledge that emphasizes on actions in specific context and by other literatures (Handley et al, 2006; Moch, 1990; Yahya and Goh, 2002). Although it is essential to have knowledge in motivating NCOs, it is also pertinent to view knowledge from the perspectives of conceptual, contextual and operational where they provide the military commanders a mental model in pursuing to motivate NCOs (Shahwanaz et al, 2008).

Specifically in the Malaysian Infantry, the Malaysian soldiers have displayed high spirit, comradeship and desire to fight against the communist in defending their country during the Malayan emergency (Ghows, 2006; Noel, 1987). Soldiers are highly motivated and willing to sacrifice in performing their military tasks against the communist insurgents (Sharom, 2006). With the laying down of arms by the communist insurgents in 1989, the Malaysian Infantry is still responsible in safeguarding the nation's sovereignty that requires the same spirit, comradeship and willingness to perform their military role but in a different environment. In this perspective, a need to examine whether the NCOs in the Malaysian Infantry are still motivated in pursuing their military tasks is necessary. Subsequently, it is also important to note that the success in military mission does not only depend on the motivation of the soldiers but also lies in the effectiveness of military commanders in motivating them (US Army, 1973). In this aspect, the need to examine the level of knowledge in motivating NCOs among military commanders in the current era is necessary. Furthermore, empirical studies on motivation in the Malaysian Infantry are limited, which makes this paper pertinent to provide a fundamental understanding in motivating NCOs for the organization and military commanders in their function of human resource management. 


\section{Literature Review}

Understanding the means to influence people to work towards organizational goals is the basic challenge faced by most organizations and the key factor for longterm success is much dependent on how organizational leaders are able to motivate their employees (Simon, 1997; Pfeffer, 1998). As influencing people is the leading function of management, motivation plays an important role in that function (Rafikul and Ahmad, 2008). In this viewpoint, it is essential to understand how to motivate people for organizations to succeed (Amar, 1998). Although knowledge on motivation has much been developed since Aldefer (1972), Herzberg et al (1959), Maslow (1970), McClelland (1985) and Vroom (1964), the need to continue the study on how motivation is influenced in the rapidly growing environment still prevails. The term motivation is often associated with the measures taken to influence a person to act in a certain way (Bartol and Martin, 1998). To make people act in a certain way, it is necessary to understand the minds of the people on what will make them act in a certain way and then establish how to influence them. In the context of this paper, a working definition for motivation is described as a process to seek the state of motivation among NCOs that drives their desire in performing military tasks. Various motivational theories provide multiple definitions of motivation. However, Roussel (2000) summarizes the concept of motivation to individual behavior that stipulates it as a process which activates, orientates and sustains behavior towards the set objectives. Ryan and Deci (2000a) also support the notion of motivation being process-oriented, which is motivation to be moved to do something. Generally, motivation theories are categorized in two approaches; content theories and process theories. Content theories explain the specific thing that motivates employees in the organization (Mullins, 1985). It emphasizes the employees' needs, their strength and the goals they desire to pursue. Content theories tend to explain the reason for people to be motivated by different ways and different work environments. In short, it explains the factors within the individual that motivate them. Among the models associated with content theories are the rational-economic model, the social model and the selfactualizing model. On the other hand, process theories are more concerned with the manner a behavior is initiated, directed or sustained (Mullins, 1985). It emphasizes on determining how motivation can be instilled, directed and sustained among individuals. Among the models associated with process theories are the complex model, expectancy-based model and equity theory of motivation.

According to Sternberg (1985), individuals are more prone to learn from experience and applying it to new problems. Tacit knowledge is not formally taught but learnt through situational experience (Sternberg et al, 2000). Tacit knowledge or knowledge-experience could be categorized into three perspectives, namely; first, interpersonal knowledge which is the knowledge about how to interact effectively with others; second, intrapersonal knowledge which is the knowledge where one learns about oneself and; third, organizational knowledge which is about how to act within the organization (Hedlund et al, 1999c; Donnithorne, 1993; Horvath et al, 1998, 1999). Knowledge is also viewed from an objectivist and subjectivist approach. From an objectivist approach, Hedlund (1994) views knowledge as objects to be discovered and in identifying it, technology is used to codify such knowledge (Hansen et al, 1999). On the other hand, the subjectivist approach refers to knowledge as inherently identified and associates with human experience and social practice of knowing (Brown and Duguid, 1998; Tenkasi and Bolland, 1996). In this perspective, knowledge is continuously shaped by the social practice of communities (Voralkulpipat and Rezgui, 2008). 
Knowledge has been viewed differently and argued by several theorists, for instance knowledge is used as information to make decisions (Fernandez et al., 2004; Kanter, 1999; Tiwana, 2002); Alonderienne et al., 2006), and information that can be made actionable (Vail, 1999). Knowledge has been contended as the experience, beliefs and values with an understanding of how to use it (Davenport and Prusak, 1998); Schubert et al., 1998; Brown and Duguid, 1998). Others have viewed knowledge as merely an individual's perception and intention (Samiotis, 2003; Hedlund, 1999; Donnithorne, 1993; Chatzkel, 2002; Shahwanaz, 2008).

In the context of military, military commanders are expected to be capable of performing leader's responsibilities with a high degree of expertise in a variety of skills. Military commanders assigned to leader's position must be able to demonstrate their knowledge and leadership skills in a constantly changing situation in the battlefield and in base camp. Although military officers are taught what to do in their military training, it is assumed that they gain experience during their operational duties on how to do the tasks learned in formal military training. If organizations are able to capture the experience gained and make it explicit, it could assist in the development of military and organizational leaders to be effective in their responsibilities of leadership. Relating to individual task, Shahwanaz et al (2008) illustrate that individual knowledge can be conceived as conceptual, contextual and operational based on Yoshioka et al (2001) knowledge framework for communicative actions. Conceptual knowledge relates to an in-depth understanding of why a person has to engage in a specific task described in a manner it has to be performed. It refers to basic principles, procedures or laws of the nature embedded in a human mind and in the society on how a particular task must be executed (Johnson et al, 2002). According to Kim (1993), conceptual knowledge of know-why implies to an understanding of experience. Contextual knowledge is the knowledge that surrounds the implementation of a specific task. More often than not, it relates to knowledge regarding the location of the task performed and the need of resources to accomplish the task, and knowledge that is temporary relating to when the task should be done (Pomeral et al, 2002). Operational knowledge is the core of the knowledge that completes the execution of the task. It is also referred to a problemsolving knowledge or domain knowledge (Dhaliwal and Benbasat, 1996). Operational knowledge relates to knowhow which at times referred to as declarative or procedural knowledge (Schultze and Leidner, 2002). It is the practical aspect of knowing how to implement the tasks with the resources made available. Fernandez et al (2004) illustrates that human knowledge is divided into two forms; tacit knowledge which is experiential, intuitive, insights and gut-feelings. It is the subjective and experience-based knowledge that is not able to be expressed formally and therefore difficult to share. On the other hand, explicit knowledge refers to one that can be expressed openly and be shared systematically in the form of data, specifications, manuals, drawings, audio, video and others alike. Even though there is a distinction between tacit and explicit knowledge, Nonaka and Takeuchi (1995) believe that tacit and explicit knowledge are mutually complementary entities, interact with and interchange into each other in the creative activities of human beings (Kathuri, 2002).

\section{Organization Setting}

The Malaysian Infantry constitutes of three infantry regiments; the Royal Malay Regiment (RMR), Royal Ranger Regiment (RRR) and the Border Regiment (BR). The Malaysian infantry is the backbone of the Malaysian Army where the prime role is to deny any form of threat or intrusion by 
land or sea. The infantry corp consists of thirty-nine regiments.

\section{Methods}

To examine the knowledge in motivating NCOs among military commanders in the Malaysian Infantry (RMR, RRR and BR), a survey was conducted in which 36 military commanders participated. The number of respondents was based on Krejcie and Morgan (1970) table for determining sample size where respondents consists of 23 military commanders form the RMR, 8 from RRR and 5 from $B R$. The respondents were asked to describe their knowledge in motivating NCOs that is conceptualized as conceptual; an understanding of motivation is important among noncommissioned officers and in motivational theories and models, contextual; an understanding of the various aspects of people, where and when to address measures in motivating non-commissioned officers and operational knowledge; an understanding on what and how actions to be taken in motivating non-commissioned officers with a Likert scale ranging from 1 (Not very well) to 5 (Very well). To examine motivating NCOs among military commanders, a general question was asked to rate how satisfied are the NCOs motivated by their military commanders in the infantry regiments with a Likert scale ranging from 1 (Not very satisfied) to 5 (Very satisfied). The respondents are the NCOs (lower ranks who are not commissioned as officers in the military) in the Malaysian Infantry. A total of 379 respondents, based on Krejcie and Morgan (1970) sample size table participated in the survey.

\section{Data Analysis and Findings}

A descriptive analysis conducted illustrates that the data obtained was normally distributed as the $p$ value was greater than the alpha value of .05 for conceptual, contextual and operational knowledge among military commanders in the RMR, RRR and BR. The normality of the distribution of data is depicted in Table 1. Reliability and validity of the survey scale are analyzed to establish the goodness of data. The reliability and validity of knowledge scale are inspected to determine how well the items in the set are positively correlated to each other (Sekaran, 2003). To determine reliability, Cronbach's alpha coefficient scale of 0.7 and above based on George et al (2006) and DeVellis (2003), rule of thumb was used. Since the respondents are only 36, a split-half reliability test was conducted using the same items and the same response format as it reflects the correlation between the two halves of the instrument to determine the reliability of the measure. The result of the split-half reliability test is shown in Table 2 . In examining the reliability test results, all items indicated positive and the Cronbach's alpha obtained was above 0.7 , indicating a good internal consistency. Furthermore, the degree each item correlated with the total score is above 0.3, indicating a good measure of scale (Pallant, 2010). 
Table 1: Tests of Normality for Level of Knowledge among Military Commanders in Motivating NCOs in Managing Motivation

\begin{tabular}{|l|l|l|c|c|c|c|c|}
\hline \multirow{2}{*}{ Level of Knowledge } & \multirow{2}{*}{ Corp } & \multicolumn{3}{|c|}{ Kolmogorov-Smirnov } & \multicolumn{3}{c|}{ Shapiro-Wilk } \\
\cline { 3 - 8 } & & Statistic & $\mathrm{df}$ & Sig. & $\begin{array}{c}\text { Statisti } \\
\mathrm{C}\end{array}$ & $\mathrm{df}$ & Sig. \\
\hline \multirow{2}{*}{$\begin{array}{l}\text { conceptual } \\
\text { knowledge }\end{array}$} & $\mathrm{RMR}$ & 0.196 & 23 & 0.023 & 0.920 & 23 & 0.066 \\
\cline { 2 - 9 } & $\mathrm{RRD}$ & 0.187 & 8 & $0.200^{*}$ & 0.877 & 8 & 0.175 \\
\cline { 2 - 9 } & $\mathrm{BR}$ & 0.231 & 5 & $0.200^{*}$ & 0.881 & 5 & 0.314 \\
\hline \multirow{2}{*}{$\begin{array}{l}\text { contextual } \\
\text { knowledge }\end{array}$} & $\mathrm{RMR}$ & 0.195 & 23 & 0.024 & 0.916 & 23 & 0.056 \\
\cline { 2 - 9 } & $\mathrm{RRD}$ & 0.228 & 8 & $0.200^{*}$ & 0.835 & 8 & 0.067 \\
\cline { 2 - 9 } & $\mathrm{BR}$ & 0.300 & 5 & 0.161 & 0.883 & 5 & 0.325 \\
\cline { 2 - 9 } knowational & $\mathrm{RMR}$ & 0.211 & 23 & 0.009 & 0.919 & 23 & 0.064 \\
\cline { 2 - 9 } & $\mathrm{RRD}$ & 0.250 & 8 & 0.150 & 0.860 & 8 & 0.120 \\
\cline { 2 - 9 } & $\mathrm{BR}$ & 0.300 & 5 & 0.161 & 0.883 & 5 & 0.119 \\
\hline
\end{tabular}

Table2: Reliability Statistics for Level of Knowledge in Motivating NCOs

\begin{tabular}{|c|c|c|c|}
\hline \multirow[t]{5}{*}{ Cronbach's Alpha } & \multirow{2}{*}{$\begin{array}{l}\text { Part } \\
1\end{array}$} & Value & 0.825 \\
\hline & & N of Items & $6^{a}$ \\
\hline & \multirow{2}{*}{$\begin{array}{l}\text { Part } \\
2\end{array}$} & Value & 0.813 \\
\hline & & N of Items & $6^{b}$ \\
\hline & & Total N of Items & 12 \\
\hline & & Correlation Between Forms & 0.958 \\
\hline \multirow{2}{*}{$\begin{array}{l}\text { Spearman-Brown } \\
\text { Coefficient }\end{array}$} & & Equal Length & 0.979 \\
\hline & & Unequal Length & 0.979 \\
\hline & & Guttman Split-Half Coefficient & 0.977 \\
\hline \multicolumn{4}{|c|}{$\begin{array}{l}\text { a. The items are: knowledge question } 1 \text {, knowledge question } 2 \text {, knowledge question } 3 \text {, } \\
\text { knowledge question } 4 \text {, knowledge question } 5 \text {, and knowledge question } 6 \text {. }\end{array}$} \\
\hline \multicolumn{4}{|c|}{$\begin{array}{l}\text { b. The question items are: knowledge question } 7 \text {, knowledge question } 8 \text {, knowledge question } \\
9 \text {, knowledge question } 10 \text {, knowledge question } 11 \text {, and knowledge question } 12 \text {. }\end{array}$} \\
\hline
\end{tabular}

The test of the homogeneity of variance as shown in Table 3 illustrates that there is no difference in the variance of the mean in the level of knowledge in motivating NCOs among military commanders. This is because the Levene statistic obtained for conceptual knowledge was valued $(F)$ of 1.188 and the corresponding $p$ value of 0.318 , for contextual knowledge is valued
$(F)$ of 1.721 and the corresponding $p$ value of 0.194 and for operational knowledge is valued $(F)$ of 0.770 and the corresponding $p$ value of 0.471 . The corresponding $p$ values are larger than the alpha value of 0.05 which concludes that the variance of the mean for the variable for this objective is homogeneous. 
Table 3: Test of Homogeneity of Variance in Level of Knowledge in Motivating NCOs

\begin{tabular}{|c|c|c|c|c|}
\hline Level of Knowledge & $\begin{array}{c}\text { Levene } \\
\text { Statistic }\end{array}$ & df1 & df2 & Sig. \\
\hline $\begin{array}{c}\text { Conceptual } \\
\text { knowledge }\end{array}$ & 1.188 & 2 & 33 & 0.318 \\
\hline Contextual knowledge & 1.721 & 2 & 33 & 0.194 \\
\hline $\begin{array}{c}\text { Operational } \\
\text { knowledge }\end{array}$ & 0.770 & 2 & 33 & 0.471 \\
\hline
\end{tabular}

Since both the normality and equality of variance were met, a one-way ANOVA was used to examine the level of knowledge in motivating NCOs among military commanders. The descriptive statistics of the One-Way ANOVA was examined for any difference in the level of knowledge. Levene's test for homogeneity of variances as shown in Table 3 indicates that the assumption of homogeneity of variance is not violated. However, based on the ANOVA Table 4, there is no significant difference in knowledge in motivating NCOs among military commanders in RMR, RRR and BR group because the corresponding $p$ values obtained for conceptual, contextual and operational knowledge between groups are greater than the alpha value of 0.05 . This concludes that knowledge in motivating NCOs among military commanders in the Malaysian Infantry is similar. Although the alpha values for contextual and operational knowledge in Table 4 are approximately 0.05 , the mean difference in the multiple comparison in Table 5 does not indicate any differences among the groups; RMR, RRR and BR. This again indicates the similarity in the level of knowledge in motivating NCOs among military commanders in the Malaysian Infantry. Hence, the finding concludes that the level of knowledge (conceptual, contextual and operational) in motivating NCOs among military commanders in RMR, RRR and BR are similar. 
Table 4: Level of Knowledge among Military Commanders in Motivating NonCommissioned Officers

\begin{tabular}{|c|c|c|c|c|c|c|}
\hline \multicolumn{7}{|c|}{ ANOVA } \\
\hline Level of Knowledge & & $\begin{array}{c}\text { Sum of } \\
\text { Squares }\end{array}$ & $\mathrm{df}$ & $\begin{array}{l}\text { Mean } \\
\text { Square }\end{array}$ & F & Sig. \\
\hline \multirow[t]{3}{*}{$\begin{array}{l}\text { conceptual } \\
\text { knowledge }\end{array}$} & $\begin{array}{l}\text { Between } \\
\text { Groups }\end{array}$ & 3.589 & 2 & 1.794 & 1.177 & .321 \\
\hline & $\begin{array}{l}\text { Within } \\
\text { Groups }\end{array}$ & 50.300 & 33 & 1.524 & & \\
\hline & Total & 53.889 & 35 & & & \\
\hline \multirow[t]{3}{*}{$\begin{array}{l}\text { contextual } \\
\text { knowledge }\end{array}$} & $\begin{array}{l}\text { Between } \\
\text { Groups }\end{array}$ & 7.489 & 2 & 3.744 & 3.129 & .057 \\
\hline & $\begin{array}{l}\text { Within } \\
\text { Groups }\end{array}$ & 39.484 & 33 & 1.196 & & \\
\hline & Total & 46.972 & 35 & & & \\
\hline \multirow[t]{3}{*}{$\begin{array}{l}\text { operational } \\
\text { knowledge }\end{array}$} & $\begin{array}{l}\text { Between } \\
\text { Groups }\end{array}$ & 7.599 & 2 & 3.800 & 3.219 & .053 \\
\hline & $\begin{array}{l}\text { Within } \\
\text { Groups }\end{array}$ & 38.957 & 33 & 1.181 & & \\
\hline & Total & 46.556 & 35 & & & \\
\hline
\end{tabular}


Table 5: Multiple Comparison: Level of Knowledge in Motivating Non-Commissioned Officers

\begin{tabular}{|c|c|c|c|c|c|}
\hline Level of Knowledge & (I) corp & $\begin{array}{l}\text { (J) } \\
\text { corp }\end{array}$ & $\begin{array}{l}\text { Mean Difference (I- } \\
\text { J) }\end{array}$ & $\begin{array}{l}\text { Std. } \\
\text { Error }\end{array}$ & Sig. \\
\hline \multirow[t]{6}{*}{ conceptual knowledge } & \multirow[t]{2}{*}{ RMR } & RRD & .250 & .507 & .875 \\
\hline & & BR & .800 & .609 & .398 \\
\hline & \multirow[t]{2}{*}{$\mathrm{RRD}$} & RMR & .250 & .507 & .875 \\
\hline & & BR & 1.050 & .704 & .308 \\
\hline & \multirow[t]{2}{*}{$\mathrm{BR}$} & RMR & .800 & 609 & .398 \\
\hline & & $\mathrm{RRD}$ & 1.050 & .704 & .308 \\
\hline \multirow[t]{6}{*}{ contextual knowledge } & \multirow[t]{2}{*}{ RMR } & RRD & .995 & .449 & .083 \\
\hline & & $\mathrm{BR}$ & .870 & .540 & .255 \\
\hline & \multirow{2}{*}{ RRD } & RMR & .995 & .449 & .083 \\
\hline & & $\mathrm{BR}$ & .125 & .624 & .978 \\
\hline & \multirow[t]{2}{*}{$\mathrm{BR}$} & RMR & .870 & .540 & .255 \\
\hline & & $\mathrm{RRD}$ & .125 & .624 & .978 \\
\hline \multirow[t]{6}{*}{ operational knowledge } & \multirow[t]{2}{*}{ RMR } & RRD & .957 & .446 & .096 \\
\hline & & BR & .957 & .536 & .191 \\
\hline & \multirow[t]{2}{*}{ RRD } & RMR & .957 & .446 & .096 \\
\hline & & BR & .000 & .619 & 1.000 \\
\hline & \multirow[t]{2}{*}{$\mathrm{BR}$} & RMR & .957 & .536 & .191 \\
\hline & & RRD & .000 & .619 & 1.000 \\
\hline
\end{tabular}

For motivating NCOs, the descriptive analysis reveals that $18.7 \%$ rated their military commanders very satisfied, while $44.6 \%$ of the respondents rated satisfied, $32.2 \%$ rated slightly satisfied and $4.5 \%$ not satisfied. Since $63.3 \%$ of the respondents rated between very satisfied and satisfied while $36.7 \%$ rated between slightly satisfied and not satisfied for their military commanders, the findings illustrates that not all military commanders in the Malaysian Infantry are able to motivate their NCOs satisfactorily. A graphical examination on the skewness and kurtosis values, normal Q-Q plot and Z score distribution of the data obtained in motivating NCOs indicates that the distribution was normal as most of the observed values fell close to or directly on the normality line. The test of the homogeneity of variance denotes that there is no difference in the variance of the mean in motivating NCOs by military commanders. This is because the Levene statistic obtained value $(F)$ of 1.950 is small and the corresponding $p$ value of 0.144 is larger than the alpha value of 0.05 . Therefore, it is concluded that the variance of the mean in motivating NCOs by military commanders is homogeneous.

Preliminary assumption was conducted to verify for normality and homogeneity of variance; no violation was observed. The ANOVA test reveal that there is a statistically significant difference in the mean of motivating NCOs by military commanders at the corps level (RMR, RRR and BR), $F(2,376)=4.973, p=0.007$. The effect size was calculated as shown below and eta-squared obtained was $\eta^{2}=0.03$, indicating that the mean difference between regiments is small (Cohen, 1988). 
$\eta^{2}=\frac{\text { SSB }}{\text { SST }}$ where

$\eta^{2}=$ Eta-squared $=$ effect size

$\mathrm{SSB}=$ Sum of squared for between groups

SST $=$ Total sum of squared

$\eta^{2}=\underline{6.234}$

241.937

$\eta^{2}=0.03$

Bonferroni Post Hoc multiple comparisons test indicate that there is a statistically significance difference in the mean of motivating NCOs by military commanders for the following pairs; $\mathrm{RMR}(M=3.82, S D=$ $0.830)$ and $\mathrm{BR}(M=3.45, S D=0.577)$ because the mean difference, $M D=0.371$ and the $p$ value obtained was 0.008 , which is smaller than alpha value of 0.05 , and RRR $(M=3.84, S D=0.791)$ and BR $(M=3.45, S D$ $=0.577$ ) because the mean difference, $M D=$ 0.388 and the $p$ value obtained was 0.017 , which is smaller than alpha value of 0.05 . On the other hand, there is no statistically significant difference between RMR $(M=$ $3.82, S D=0.830)$ and $\operatorname{RRR}(M=3.84, S D=$ 0.791 ) because the mean difference, $M D=$ 0.18 is small and the $p$ value obtained was 1.000 , which is greater than alpha value of 0.05 . The mean difference obtained in motivating NCOs by military commanders between the three regiments may be small due to factors such as similarity in command and organizational structure, or similar military training and career development among the military commanders.

\section{Discussion}

First, the findings of this study indicate that there was no significant difference in the level of knowledge in motivating NCOs among military commanders in the corps (RMR, RRR and BR) because the corresponding $p$ values obtained for conceptual, contextual and operational knowledge between groups was greater than the alpha value of 0.05 and the mean difference in the multiple comparison table did not indicate any differences among the groups; RMR, RRR and BR. Hence, the findings conclude that the level of knowledge (conceptual, contextual and operational) in motivating NCOs among military commanders in RMR, RRR and BR are similar. The result implies that the general military courses the military commanders have undergone as part of training and development are sufficient for them to have the knowledge in motivating their subordinates. Second, the findings in motivating NCOs indicate that $63.3 \%$ of the respondents rated their military commanders between very satisfied and satisfied while $36.7 \%$ rated between slightly satisfied and not satisfied. This result implies that not all military commanders in the Infantry are able to motivate their NCOs satisfactorily An assumption is that factors relating to experience may have an influence on the difference in motivating NCOs. This assumption is supported by the studies of Hitt and Tyler (1991), Thomas et al (1991) and Moynihan and Pandey (2007a) which state that age has an influence over the manner a job or task is carried out and that it reflects experience gained as one matures in an organization. In addition, Kakabadse and Kakabadse (1998) also indicate the influence of age factor over organizational leader's behavior and attitudes. The age factor is also associated with individual experience and personal knowledge accumulated which has an influence over a leader's action in the organization (Wagner et al, 1984; Konrad and Hartmann, 2002, Kakabadse and Kakabadse, 1998; Moynihan and Pandey, 2007). These researches illustrate a relationship between age and experience gained over time (maturity), and reflects a positive view on leader's behavior and attitude in their job responsibility. 
Moreover, Chia and Holt (2008), Zhang et al (2010) and Zollo and Writher (2007) assert that experience reflected in age is an essential element of knowledge and thus links a relationship between age and knowledge. Length of time in organization and length of time in job position (tenure) is another factor associated with age and job attitude where length of time spent in the organization reflects the development of experience (Wiersema and Bird, 1993). This relates to the ability of a leader to manage human resource (Finkelstein and Hambrick, 1990; Pfeffer, 1993). These studies relate that the ability of a leader lies in the experience accumulated leading to knowledge enhancement which is expressed in Moynihan and Pandey (2007), Chia and Holt (2008) and Zhang et al (2010) studies.

\section{Conclusion}

In summary, the results empirically illustrate that although all military commanders have a similar level of knowledge, not all are able to put the knowledge into practice in motivating their NCOs satisfactorily. Next, the difference in the ability of military commanders in motivating NCOs could be influenced by experience reflected from age, maturity and length of time in job position (Wagner et al, 1984; Konrad and Hartmann, 2002, Kakabadse and Kakabadse, 1998; Moynihan and Pandey, 2007). Since studies on motivation in the Malaysian Infantry are limited, this study proposes further research to determine, i) whether experience reflected as age, maturity and length of time in job position influences the ability to motivate NCOs among military commanders; and ii) military commanders who are able to motivate NCOs satisfactorily and elicit relevant knowledge from them for learning and training purposes. This will also assist the current and potential military commanders to enhance their human resource management function in the military.

\section{References}

Alderfer, C. P. (1972). Existence, Relatedness and Growth: Human Needs in Organizational Settings, Free Press New York, NY.

Alonderienne, R., Pundziene, A. \& Krisciunas, K. (2006). "Tacit Knowledge Acquisition and Transfer in the Process of Informal Learning," Problems and Perspectives in Management, 4 (3), 135145.

Amar, A. D. (1998). "Controls and Creativity in Organizations," The Mid-Atlantic Journal of Business, 34, 97-99.

Bartol, K. M \& Martin, D. C. (1998). 'Management, 3rd ed,' New York: McGrawHill, New York.

Ben-Dor, G., Pedahzur, A., Canetti-Nisim, D., Zaidise, E., Perliger, A. \& Bermanis, S. (2008). "I versus We: Collective and Individual Factors of Reserve Service Motivation during War and Peace," Armed Forces and Society, 34 (4), 565-592.

Blocq, D. (2010). "Western Soldiers and the Protection of Local Civilians in UN Peacekeeping Operations: Is Nationalist Orientation in the Armed Forces Hindering our Preparedness to Fight?," Armed Forces and Society, 36 (2), 290- 309.

Brown, J. S. \& Duguid, P. (1991). 'Organizational Learning and Communitiesof-Practice,' in M. Cohen and L.S. Sproull (eds) Organizational Learning. London: SAGE, 58-82.

Brown, J. S. \& Duguid, P. (1998). "Organizing Knowledge," California Management Review, 40 (3), 90-112.

Catignani, S. (2004)."Motivating Soldiers: the Example of the Israeli Defence Forces," Parameters (Autumn). 
Chatzkel, J. (2002). "Conversation with Alex Bennet, Former Deputy CIO for Enterprise Integration at the U.S. dept of Navy," Journal of Knowledge Management, 6(5), 434-444.

Chia, R. \& Holt, R. (2008). "On Management Knowledge," Management Learning, 39 (2), 141-158.

Chua, A. Y. K., Lam, W. \& Majid, S. (2006). "Knowledge Reuse in Action: The Case of CALL," Journal of Information Science, 32 (3) 251-160.

Cole, G. A. (2004). Management: Theory and Practice (6th ed), Thomson Learning, Padstow, Cornwall.

Davenport, T. H. \& Prusak, L. (1998).Working Knowledge: How Organizations Manage What They Know, Boston, MA: Harvard Business School Press.

DeVellis, R. F. (2003). Scale Development: Theory and Applications, 2nd ed, Thousand Oaks, California: Sage.

Dhaliwal, J. S. \& Benbasat, I. (1996). "The Use and Effects of Knowledge-Based Systems Explanations: Theoretical Foundations and a Framework for Empirical Evaluation," Information System Research, 7 (3), 342-362.

Dingley, J. C. (1986). "Recent Developments in the Area of Motivation," Journal of IMDS, July/ August, 21-24.

Dixon, M. A. (2003). 'The Application of Knowledge Management in Defence,' Australian Defence Journal, 159.

Donnithorne, L. R. (1993). 'The West Point Way of Leadership,' Currency Doubleday.

Erkutlu, H. (2008). "The Impact of Transformational Leadership on Organizational and Leadership
Effectiveness," Journal of Management Development, 27 (7), 708-726.

Fernandez, I. B., Gonzalez, A. J. \& Sabherwal, R. (2004). Knowledge Management Challenges, Solutions and Technologies, Upper Saddle River, New Jersey: Pearson Prentice Hall.

Finkelstein, S. \& Hambrick, D. C. (1990). "Top Management Team Tenure and Organizational Outcomes: The moderating of Managerial Discretion," Administrative Science Quarterly, 35 (3) , 484.

George, D \& Mallery, P. (2006). 'SPSS for Windows Step by Step: a Simple Guide and Reference,' 13.0 Update, 6th ed, Allyn and Bacon, USA.

Ghows, M. A. M. H. (2006). 'The Malayan Emergency Revisited 1948-1960,' Kuala Lumpur, AMR Holdings Sdn Bhd.

Greger, K. R. \& Peterson. J. S. (2000). "Leadership Profile for the New Millennium," Cornell Hotel and Restaurant Administration Quarterly 41(16), 16-29.

Guzman, G. (2009). "What is Practical Knowledge?," Journal of Knowledge Management, 13 (4), 86-98.

Handley, K., Sturdy, A., Fincham, R. \& Clark, T. (2006). "Within and Beyond Communities of Practice: Making Sense of Learning through Participation, Identity and Practice," Journal of Management Studies, 43 (3), 641-53.

Hansen, M. T., Nohria, N. \& Tierney, T. (1999). "What's Your Strategy for Managing Knowledge?," Harvard Business Review, 77 (2), 106-116.

Hedlund, G. (1994). "A Model of Knowledge Management and the N-Form Corporation," Strategic Management Journal, Vol 15, 7390. 
Hedlund, J, Forsythe, G. B., Horvath, J. A., Williams, W. M., Snook, S. \& Sternberg, R. J. (2003). "Identifying and Assessing Tacit Knowledge: Understanding the Practical Intelligence of Military Leaders," Leadership Quarterly, 14 (2).

Hedlund, J., Williams, W. M., Horvath, J. A., Forsythe, G. B., Snook, S., Wattendorf, J., Mcnally, J. A., Sweeney, P. J., Bullis, R. C., Dennis, M. \& Sternberg, R. J. (1999c). "Tacit Knowledge for Military Leaders: Battalion Commander Questionnaire (Research Product 99-09)," Alexandria, VA: U.S. Army Research Institute for the Behavioral and Social Sciences.

Herzberg, F., Maunser, B. \& Synderman, B. (1959). The Motivation to Work, New York: Wiley, NY.

Hitt, M. A. \& Tyler, B. B. (1991). "Strategic Decision Models: Integrating Different Perspectives," Strategic Management Journal, 12, 327-352.

Horvath, J. A., Forsythe, G. B., Bullis, R. C., Sweeney, P. J., Williams, W. M., Mcnally, J. A., Watteendorf, J. M. \& Strenberg, R. J. (1999).Experience, Knowledge and Military Leadership in R. J. Sternberg \& J. A. Horvath (Eds), Tacit Knowledge In Professional Practice, Mahwah, NJ: Lawrence Erlbaum Associates, 39-57

Horvath, J. A., Sternberg, R. J., Forsythe, G. B., Sweeney, P. J., Bullis, R. C., Williams, W. M. \& Dennis, M. (1998). 'The Tacit Knowledge for Military Leaders (Research Product 99-07, 99-08, 99-09),' Alexandria, VA: U.S. Army Research Institute for the Behavioral and Social Sciences.

Johnson, B., Lorenz, E. \& Lundvall, B.- A. (2002). "Why All This Fuss About Codified And Tacit Knowledge?," Industrial and Corporate Change, 11 (2), 245-262.
Kanter, J. (1999). "Knowledge Management, Practically Speaking. Information Systems Management," Fall, 715.

Kathuri, S. (2002). 'Knowledge in Organizations Definition, Creation and Harvesting,' Harvard Edu Spring.

Kim, D. H. (1993). The Link between Individual and Organizational Learning, Sloan Management Review, 35 (1), 37-51.

Konrad, A. M. \& Hartmann, L. (2002). "Gender Differences in Attitudes Toward Affirmative Action Programs in Australia: Effects of Beliefs, Interests and Attitudes Towards Women," Gender Roles, 45 (5-6), 415-432.

Korac-Kakabadse, A. Korac-Kakabadse, N. \& Myers, A. (1998). "Demographics and Leadership Philosophy: Exploring Gender Differences," Journal of Management Development, 17 (5), 351-388.

Krejcie, R. V. \& Morgan, D. W. (1970). "Determining Sample Size for Research Activities," Educational and Psychological Measurement, 30, 607-610.

Kunich, J. C. \& Lester, R. L. (1994). "Profile of a Leader: the Wallenberg Effect," The Journal of Leadership Studies,1 (2), 94-107.

Lambe, P. (2003). "Knowledge and Tragedy: or Why we Shouldn't Share Knowledge," Www.Straitsknowledge.Com.

Lewin, E. (2006). "Are Patriots Really More Patriotic Than Their Anti-Patriotic Rivals? Poking Into Patriotism Through the Israeli Case," A Worldwide Journal of Politics, (Fall). 
Maccoun, R. J., Kier, E. \& Belkin, A. (2005). "Does Social Cohesion Determine Motivation in Combat? an Old Question with and Old Answer," Armed Forces And Society, 32 (1).

Maslow, A. H. (1970). Motivation and Personality, New York: Harper, $N Y$.

Mcclelland, D. C. (1985). Human Motivation, Scott, Glenview, IL.

Mclntyre, S. G., Gauvin, M. \& Waruszynski, B. (2003). "Knowledge Management in the Military Context," Canadian Spring Journal.

Moch, S. D. (1990). "Personal Knowing: Evolving Research and Practice," Scholarly Inquiry for Nursing Practice, 4 (2), 155-65.

Moynihan, D. P. \& Pandey, S. K. (2007a). "The Role of Organization in Fostering Public Service Motivation," Public Administration Review, 67 (1), 40-53.

Mullins, L. J. (1985). "The Process of Motivation," IMDS, March/ April, 5-8.

Mumford, M. D. (2000). "Managing Creative People: Strategies and Tactics for Innovation," Human Resource Management Review, 10 (3), 313-351.

Noel, B. (1987). The War of the Running Dogs: the Malayan Emergency, 1948-1960, London, Bantam Books.

Nonaka, I. \& Takeuchi, H. (1995). "The Knowledge-Creating Company," New York, Oxford University Press.

Pallant, J. (2010). SPSS Survival Manual: a Step by Step Guide to Data Analysis Using SPSS for Windows, 4th Ed, Mcgraw Hill, England.

Pfeffer, J. (1998). The Human Equation: Building Profits by Putting People First. Cambridge, MA: Harvard Business School Press.
Pomerol, J.- C., Brezillion, P. \& Pasquier, L. (2002). "Operational Knowledge Representation for Practical Decision Making," Journal of Management Information Systems, 18 (4),101-115.

Primoratz \& Igor (Ed). (2002). 'Patriotism. Amberst,' New York: Humanity Books.

Proctor, M. D. \& Gubler, J. C. (1998). "Military Simulation Worlds and Organizational Learning," Proceedings of the 1998 Winter Simulation Conference.

Rafikal, I. \& Ahmad, Z. H. I. (2008). "Employee Motivation: a Malaysian Perspective," International Journal of Commerce and Management, 18 (4).

Roussel, P. (2000). 'Concept of Theories,' Interdisciplinary of Human Resource, Note: 326.

Ryan, R. M. \& Deci, E. L. (2000a). "Intrinsic and Extrinsic Motivations: Classic Definitions and New Directions," Contemporary Educational Psychology, 25:54-67.

Samiotis, K., Poulymenakou, A. \& Doukidis, G. (2003). "Understanding Knowledge Management Interventions: Evidence from Supporting (E-) Banking Activities," Knowledge \& Process Management, 10(3), 175-182.

Schubert, P., Lincke, D. \& Schmid, B. (1998). 'A Global Knowledge Medium as a Mutual Community: the Net Academy Concept,' Proceedings of the Fourth Americas Conference on Information Systems, Baltimore, MD.

Schultze, U. \& Leidner, D. (2002). “Studying Knowledge Management in Information Systems Research: Discourses and Theoretical Assumptions," MIS Quarterly, 26 (3), 213-242. 
Sekaran, U. (2003). Research Methods for Business: a Skill Building Approach, 4th Ed, Wiley and Sons, New Delhi, India.

Shahnawaz, M., William, J. D. \& Xiaodong D. (2008). 'Proceedings of the 41st Hawaii International Conference on System Sciences,'

Sharom, H., (2006). 'The Malayan Army's Battle Against Communist Insurgency in Peninsula Malaysia,' 1968-1989, Kuala Lumpur, AHQ, MINDEF.

Simon, H. (1997). 'Administrative Behavior: a Study of Decision-Making Processes in Administrative Organizations (5thed),' New York: Macmillan.

Srinivasan, M. S. (2008). "Motivation and Human Growth: a Development Perspective," Journal of Human Value, 14 (1), 63-71.

Sternberg, R. J. (1985). 'Beyond IQ: a Triarchic Theory of Human Intelligence,' New York: Cambridge University Press.

Sternberg, R. J., Forsythe, G. B., Hedlund, J., Horvath, J. A., Wagner, R. K., Williams, W. M., Snook, S. A. \& Grigorenko, E. L. (2000). Practical Intelligence in Everyday Life. Cambridge, UK: Cambridge University Press.

Tenkasi, R. V. \& Boland, R. J. (1996). "Exploring Knowledge Diversity in Knowledge Intensive Firms: a New Role for Information Systems," Journal of Organizational Change Management, 9 (1), 79-91.

Thomas, A. S., Litschert, R. J. \& Ramaswamy, K. (1991). "The Performance Impact of Strategy-Manager Co Alignment: an Empirical Examination," Strategic Management Journal, 12, 509-522.

Tiwana, A. 2002. The Knowledge Management Toolkit: Orchestrating IT, Strategy and Knowledge platforms. New Jersey: Prentice Hall.
Tsoukas, H. (2000). "Knowledge as Action, Organization as Theory: Reflections on Organizational Knowledge," Emergence, 2 (4), 104-12.

'US Army: Field Manual on Military Leadership,' (1973), FM 22-100.

Vail, E. F. (1999). "Knowledge Mapping: Getting Started with Knowledge Management," Information Systems Management, 16 (4), Pp. 16-23.

Voralkulpipat, C. \& Rezgui, Y. (2008). "An Evolutionary and Interpretive Perspective to Knowledge Management," Journal of Knowledge Management, 12 (3), 17-34.

Vroom, V. H. (1964). Work and Motivation. New York: Wiley.

Wagner, W. G., Pfeffer, J. \& O'Reilly, C. A. (1984). "Organizational Demography and Turnover in Top Management Groups," Administration Science Quarterly, 29, 74-

Weick, K. E. (1995). Sensemaking in Organizations, Sage, Thousand Oaks, CA.

Wiersema, M. F. \& Bird, A. (1993). "Organizational Demography in Japanese Firms: Group Heterogeneity, Individual Dissimilarity, and Top Management Team Turnover," Academy of Management Journal, 38 (5), 996-1026.

Wright, P. M. \& Mcmahan, G. C. (1992). "Theoretical Perspectives for Strategic Human Resource Management," Journal of Management, 16 (10), Pp171-174.

Yahya, S. \& Goh, W.- K. (2002). "Managing Human Resources towards Achieving Knowledge Management," Journal of Knowledge Management, 6 (5), 457-468.

Yoshioka,T., Herman, G., Yates, J. \& Orlikowski, W. (2001). "Genre Taxanomy: a Knowledge Repository of Communicative Actions," ACM Transaction on Information Systems 19 (4). 431-456. 
Zaccaro, S. J. \& Horn, Z. N. J. (2003). "Leadership Theory and Practice: Fostering an Effective Symbiosis," The Leadership Quarterly, 14, 769-806.

Zhang, J., Soh, P.- H. \& Wong, P.- K. (2010). "Entrepreneurial Resource Acquisition through Indirect Ties: Compensatory Effects of Prior Knowledge," Journal of Management, 36 (2), 511-536.

Zollo, M. \& Winter, S. G. (2002). "Deliberate Learning and the Evolution of Dynamics Capabilities," Organization Science, 13 (3), 339-351. 